\title{
Pakistan 2011: Policy Measures for the Economic Challenges
}

\begin{abstract}
Ahead
Shahid Amjad Chaudhry*

Abstract

Pakistan faces economic challenges in the summer of 2011 with regard to its balance of payments and its public finances, resulting primarily from the suspension of an ongoing International Monetary Fund (IMF) program, the associated cessation of program lending by other multilateral financial institutions, and the termination of the US's cash logistics support. This paper argues that these challenges can be met without resorting to a new program with the IMF. The policy measures recommended with regard to the balance of payments are: (i) to allow the orderly depreciation of the exchange rate in the foreign exchange interbank market by about 5-15 percent or to PKR90-100/US dollar, (ii) to impose import surcharges of 10-20 percent on nonessential imports, and (iii) to re-impose measures originally imposed to increase the cost of import letters of credit. Public finance-related policy measures recommended on the expenditure side are: (i) to gradually reduce the State Bank of Pakistan's policy rate by 300 basis points in the fiscal year (FY) 2012 from its present level of 13.5 percent, thereby reducing the interest burden on public debt; and (ii) to utilize these savings to restart the stalled public sector infrastructure development program. These measures will also stimulate economic activity. On tax policy, the paper recommends that: (i) the sales tax rate be increased from its present 16 percent to 18 percent, (ii) custom duties be increased by 10-20 percent on nonessential imports (as also recommended for the balance of payments, and (iii) regulatory and excise duties be increased and their original (FY2011) coverage restored.
\end{abstract}

Keywords: Economic Policy, Balance of Payments, Public Finance, Pakistan.

JEL Classification: H29, G18.

*Rector, Lahore School of Economics and Former Deputy Chairman of the Planning Commission, Government of Pakistan. 


\section{Introduction}

Pakistan entered into an International Monetary Fund (IMF) program in late 2008 as its foreign exchange reserves depleted as a result of economic adventurism during 2004-08 by its economic managers. The IMF program was generally implemented during 2009 and 2010 but finally suspended in the summer of 2011, which was also notable in that the US cut off its cash logistics support program (roughly USD1 billion per annum) to Pakistan. These twin events followed in the wake of exceptional floods in the summer of 2010, which displaced about 20 million people, and caused a loss in infrastructure estimated at about USD10 billion and an income loss estimated at about 2-3 percent of gross domestic product (GDP). As a result, Pakistanis are generally concerned about the future direction of the economy and particularly the policy options available to them. This paper aims to address some of these issues.

\section{Economic Fundamentals}

Pakistan, with an area of 877,365 square kilometers; a population of 175 million; more than a dozen urban centers of more than 1 million people (Karachi, 12 million; Lahore, 7 million); large agricultural areas (in excess of 50 million acres); and possessing a sophisticated industrial, scientific, and financial infrastructure is easily a significant political, economic, and social entity on the world scene.

As Table 1 below indicates, the country's current GDP is about USD235 billion at current market prices (probably about USD500 billion at purchasing power parity $[\mathrm{PPP}]$ prices) and its per capita income about USD1,400 (USD3,000 at PPP prices). It is also a large and flourishing democracy with a fiercely independent media and judiciary. An economy and society of this size and sophistication should be able to manage its current economic problems, which essentially stem from a low growth rate/high interest rate syndrome imposed by the IMF, and an apparent financial squeeze imposed by other multilateral financial institutions (the World Bank and Asian Development Bank) after the breakdown of the agreement with the IMF. 
Table 1: Pakistan's Economic Fundamentals

(At current market prices)

\begin{tabular}{lrrr}
\hline & $\mathbf{2 0 0 9 / 1 0}$ & $\begin{array}{c}\mathbf{2 0 1 0 / 1 1} \\
\text { Estimates }\end{array}$ & $\begin{array}{c}\mathbf{2 0 1 1 / 1 2} \\
\text { Projected }\end{array}$ \\
\hline GDP (PKR billion) & 14,836 & 18,063 & 21,173 \\
GDP (USD billion) & 177 & 211 & 235 \\
GNP (PKR billion) & 15,402 & 18,847 & 21,973 \\
GNP (USD billion) & 184 & 220 & 244 \\
Population (million) & 170 & 173 & 177 \\
Exchange rate (USD1 = PKR) & 83.6 & 85.6 & 90.0 \\
GNP/capita (PKR) & 90,600 & 108,940 & 124,140 \\
GNP/capita (USD) & 1,083 & 1,272 & 1,380 \\
GDP growth rate at current prices (\%) & 15.1 & 21.7 & 17.2 \\
GDP growth rate at constant prices (\%) & 4.4 & 2.4 & 4.2 \\
CPI (\%) & 12.7 & 13.1 & $11-12$ \\
State Bank of Pakistan's policy rate (\%) & 12.5 & 14.0 & 13.5 \\
\hline
\end{tabular}

$\mathrm{CPI}=$ consumer price index, $\mathrm{GDP}=$ gross domestic product, $\mathrm{GNP}=$ gross national product.

Sources: GDP and GNP data and projections from the Planning Commission's Annual Plan, 2011-12 (pp. 11-12). Exchange rates for 2009/10 and 2010/11 from the Finance Division's Pakistan Economic Survey 2010-11 (p. 86). Exchange rate for 2011/12 is author's own estimate. CPI and SBP reverse repo rate (policy rate) from the State Bank of Pakistan's Monetary Policy Statement, July 2011 (pp. 1-24).

\section{Balance of Payments}

Consequent to the boom-and-bust policies followed by Pakistan in the 1980s and early 1990s, essentially involving in each case a balance of payments crisis and subsequent recourse to the IMF, Pakistan moved to institute an orderly market-determined exchange rate. Instead of a fixed exchange rate managed by the State Bank of Pakistan (SBP), an interbank foreign exchange market was created in the late 1990s by the SBP whereby all exporters (including banks and foreign currency exchange houses with foreign exchange from workers' remittances or currency exchange) were required to sell their foreign exchange within 30 days in the interbank market to importers of goods and services. This market (supervised by and intervened in by the SBP) ensured that the exchange rate would adjust according to market realities and Pakistan could consequently hold any desired level of foreign exchange reserves.

This automatic mechanism served Pakistan well until November 2004 when the SBP decided to remove all oil payments from the interbank market and provide it with foreign exchange directly, using its own 
reserves or its own purchases from the interbank market. This fateful decision, largely stemming from a desire to maintain the exchange rate at current levels—then approximately USD1 = PKR60-had severe consequences. The exchange rate appreciated dramatically in real terms over the next four years, resulting in unrestrained imports and consumption of imported goods, and with consequent adverse effects for the balance of payments. As oil prices rose from an average of USD41/barrel in the fiscal year (FY) 2005 to USD92/barrel in FY2008 (SBP, 2010a, p. 60), the SBP oil support amounted to USD6.7 billion in FY2006, USD7.3 billion in FY2007, and USD11.5 billion in FY2008 (Table 2). As a result, Pakistan's gross foreign exchange reserves fell from USD11.3 billion in end-June 2008 to USD6.8 billion by October 2008, of which about USD2.5 billion were reserves of commercial banks' private depositors. This necessitated immediate recourse to an IMF program.

Table 2: Pakistan's Balance of Payments (In USD billion, current prices)

\begin{tabular}{lccccc}
\hline & FY2007 & FY2008 & FY2009 & FY2010 & $\begin{array}{c}\text { FY2011 } \\
\text { Estimates }\end{array}$ \\
\hline SBP gross reserves & 16.8 & 11.3 & 12.1 & 16.9 & NA \\
$\begin{array}{l}\text { SBP net reserves } \\
\text { IMF support }\end{array}$ & 13.3 & 8.6 & 9.5 & 13.1 & 14.8 \\
$\begin{array}{l}\text { Balance of payments/overall } \\
\text { balance }\end{array}$ & 3.7 & -5.5 & -3.1 & 1.3 & 2.5 \\
\hline Capital account balance & 10.4 & 8.3 & 6.1 & 5.2 & 1.8 \\
$\begin{array}{l}\text { Direct investment } \\
\text { Portfolio investment }\end{array}$ & 5.1 & 5.4 & 3.7 & 2.2 & 1.5 \\
Foreign loans (net) & 3.3 & 0.0 & -1.1 & 0.0 & 0.7 \\
\hline Current account balance & 2.0 & 2.8 & 2.1 & 2.0 & 0.2 \\
Trade balance & -6.9 & -13.8 & -9.3 & -3.5 & 0.5 \\
Exports & -9.7 & -15.0 & -12.6 & -11.4 & -10.2 \\
$\begin{array}{l}\text { Imports } \\
\text { (Petroleum and crude oil) }\end{array}$ & 17.3 & 20.4 & 19.1 & 19.6 & 25.5 \\
\hline Services and current transfers & 27.0 & 35.4 & 31.7 & 31.0 & 35.7 \\
balance & $(7.3)$ & $(11.5)$ & $(9.5)$ & $(10.1)$ & $(11.1)$ \\
Workers' remittances & & 1.2 & 3.3 & 7.9 & 10.7 \\
$\begin{array}{l}\text { US cash logistics support (CSF) } \\
\text { and budgetary support }\end{array}$ & 5.5 & 6.4 & 7.8 & 8.9 & 11.2 \\
\hline
\end{tabular}

FY = fiscal year, IMF = International Monetary Fund, SBP = State Bank of Pakistan.

Sources: SBP's Annual Reports for 2007/08, 2008/09, and 2009/10 (excluding commercial bank reserves of private foreign exchange deposits). SBP's Monetary Policy Statement, July 2011 (p. 21) for FY2010/11. 
The IMF program provided Pakistan with about USD3.9 billion in FY2009 and USD3.5 billion in FY2010 before being suspended in FY2011 when the country failed to adopt a revised general sales tax (RGST) or value-added tax (VAT) as envisaged in the FY2011 (July 2010-June 2011) budget. Besides its importance in providing the economy with the necessary liquidity, a major feature of the IMF program was that it had shifted petroleum imports back to the foreign exchange interbank market starting in February 2009 and completing this process in December 2009. For FY2009, the SBP provided USD9.2 billion in foreign exchange against this head against USD999 million provided by the banks. In FY2010, the SBP provided only USD2.1 billion in foreign exchange (till December 2009), while the banks provided USD8.6 billion. This foreign exchange interbank market process for petroleum imports (and indeed for all import payments) is now firmly back in place, eliminating an important source of instability in the foreign exchange reserve accounts. As a result, the SBP's intervention in the foreign exchange interbank market is now very limited.

However, a negative consequence of the now almost defunct IMF program has been that other multilateral financial institutions (the World Bank and Asian Development Bank) have cut off their program lending to Pakistan in order to pressure it to adopt another IMF program, while their own project lending has been substantially reduced due to the lack of counterpart funding in Pakistan's Federal Public Sector Development Program, which was cut back drastically to meet IMF budget deficit targets (discussed later). As a result, capital inflows from multilateral and other institutions in FY2011 are down from an expected USD4.8 billion to approximately USD2.4 billion (SBP, 2011, p. 22) —an amount just about equal to the amortization due to these institutions, resulting in a net inflow of only USD0.2 billion under this head. While this data is very preliminary and may well change as additional data becomes available, the situation on the capital and financial accounts is a source of considerable concern.

This dismal picture of the capital account is, however, at least temporarily offset by the spectacular growth in workers' remittances to USD11.2 billion in FY2011 compared to USD8.9 billion in FY2010, and the equally impressive growth in merchandise exports-USD25.5 billion in FY2011 compared to USD19.6 billion in FY2010. The increase in workers' remittances is expected to be sustained while merchandise exportswhich benefitted from higher unit prices as a result of a commodity boom-are likely to consolidate and increase at a more modest level in the future as a result of declining cotton and other prices. 
The policy measures recommended for Pakistan while it continues to pursue increased capital flows are, therefore, to: (i) allow the exchange rate to depreciate in the interbank market in an orderly manner by an estimated 5-15 percent-as the foreign exchange market tightens-to between PKR90 and PKR100 per dollar; (ii) impose import surcharges comprising an additional 10-20 percent customs duty on all imports excluding petroleum products, raw materials, and security-related imports.

Ideally, nonessential consumer goods will have at least an additional 20 percent customs duty. It is recommended that more weight be given to import surcharges since this will mitigate the extent of the exchange rate adjustment required, and also help the fiscal situation (discussed further below). In addition, (iii) the SBP, which had recently withdrawn its additional cash and other requirements for opening import letters of credit (perhaps at the urging of the IMF), should re-impose these earlier measures.

\section{Federal Public Finances}

The Seventh National Finance Commission award was signed on 30 December 2009, under which the provinces' share in federal taxes was increased from 46.75 percent in FY2010 to 56.70 percent in FY2011 and 57.50 percent in all subsequent years. In addition, the $18^{\text {th }}$ Amendment to the Constitution was approved on 9 April 2010 through which the Concurrent List (defining areas of joint federal and provincial legislation) was abolished and all its subjects transferred to the provinces, with the exception of a few-notably criminal law and procedure; and standards in higher education institutions, science and technical institutions, and legal, medical, and other professions-which were moved to Part II of the Federal List that is administered by the Council of Common Interests comprising the federal government and the provinces (Beaconhouse National University, 2011, pp. 62-63).

As Table 3 indicates, the Seventh National Financial Commission Award severely restricted federal finances in FY2011 to PKR2,620 billion, which was only 4 percent higher than the PKR2,517 billion available in FY2010 (a period during which the consumer price index [CPI] increased by 13.1 percent). While 15 federal ministries were moved to the provinces (including local government, education, social welfare, food and agriculture, health, and labor and manpower), slimming down the federal

government did not mitigate the severe adjustment the federal public 
finances had to undertake to meet the IMF program's fiscal deficit targets of 4-5 percent of GDP (Beaconhouse National University, 2011, pp. 64-65).

Table 3: Pakistan's Federal Public Financial Resources

(In PKR billion, current prices)

\begin{tabular}{llrrrr}
\hline & FY2009 & FY2010 & $\begin{array}{c}\text { FY2011 } \\
\text { (Revised Est.) }\end{array}$ & $\begin{array}{r}\text { FY2012 } \\
\text { Budget }\end{array}$ \\
\hline 1 & Total internal receipts & 1,970 & 2,237 & 2,554 & 3,032 \\
& (Tax revenues divisible pool) & $(1,180)$ & $(1,483)$ & $(1,679)$ & $(2,074)$ \\
& (Nontax revenues) & $(603)$ & $(569)$ & $(556)$ & $(657)$ \\
& (Capital receipts) & $(187)$ & $(185)$ & $(319)$ & $(299)$ \\
2 & Total external receipts & 367 & 578 & 290 & 414 \\
3 & Public accounts receipts & 64 & 191 & 201 & 164 \\
4 & Gross federal resources (1+2+3) & 2,401 & 3,006 & 3,046 & 3,610 \\
5 & Less provincial share of & 560 & 655 & 998 & 1,203 \\
& divisible pool & & & & \\
6 & Net federal resources (4-5) & 1,841 & 2,350 & 2,048 & 2,406 \\
7 & Cash buildup by provinces & 37 & 78 & 119 & 124 \\
8 & Credit from banking sector & 146 & 89 & 452 & 303 \\
9 & Total federal resources (6+7+8) & 2,024 & 2,517 & 2,620 & 2,835 \\
\hline
\end{tabular}

$\mathrm{FY}=$ fiscal year.

Sources: Finance Division's Federal budget: Budget in brief, 2008-09 for FY2009. Finance Division's Federal budget: Annual budget statement for 2009/10, 2010/11, and 2011/12 for FY2010, FY2011, and FY2012, respectively.

Unfortunately, as always, the federal Public Sector Development Program (PSDP) had to bear the burden of the downward adjustmentfrom PKR229 billion in FY2009 to PKR138 billion in FY2010 and PKR99 billion in FY2011 (Table 4) with dramatic adverse consequences for federal public infrastructure development and the colossal waste inflicted on the national economy when ongoing projects of national importance in roads, highways, water, power, health, and education ceased to be financed.

An analysis of federal financial expenditures (Table 4) shows the squeeze on both the current and capital (development) expenditures of the federal government. Current expenditures, excluding debt service (primarily interest payments), are projected to be reduced from PKR1,501 billion in FY2011 to PKR1,349 billion in FY2012, or by 11 percent at a time when CPI inflation for the current fiscal year (FY2012) is estimated at 1112 percent. This 20 percent real reduction in current expenditures for FY2012) is clearly unsustainable, and is due to the unrealistic (and self- 
inflicted) bleeding of public finances caused by a very high level of debt service, which is primarily the result of the SBP's present (August 2011) reverse repo rate (policy rate) of 13.5 percent that has led to high interest rates in the economy and for government borrowing. Each 100-basis points or 1 percent drop in the SBP's policy rate will result in a gain of approximately PKR75 billion to federal public finances. A 300-basis points or 3 percent drop in the policy rate will make available resources sufficient to restore the federal PSDP to its earlier levels in real terms.

Table 4: Pakistan's Federal Public Financial Expenditure (In PKR billion, current prices)

\begin{tabular}{lrrcr}
\hline & FY2009 & FY2010 & $\begin{array}{r}\text { FY2011 } \\
\text { (Revised Est.) }\end{array}$ & $\begin{array}{c}\text { FY2012 } \\
\text { (Budget) }\end{array}$ \\
\hline Total federal expenditure & 2,024 & 2,517 & 2,620 & 2,835 \\
Current expenditure & 1,649 & 2,132 & 2,356 & 2,383 \\
$\quad(D e f e n s e)$ & $(311)$ & $(378)$ & $(445)$ & $(495)$ \\
$\quad(D e b t$ service) & $(752)$ & $(814)$ & $(855)$ & $(1,034)$ \\
Development expenditure & 375 & 384 & 263 & 451 \\
$\quad($ PSDP) & $(229)$ & $(138)$ & $(99)$ & $(177)$ \\
(Other development a/c) & $(59)$ & $(118)$ & $(46)$ & $(197)$ \\
(Development expenditure & $(87)$ & $(127)$ & $(118)$ & $(178)$ \\
on capital a/c) & & & & \\
\hline
\end{tabular}

FY = fiscal year, PSDP = Public Sector Development Program.

* PSDP includes operational shortfall except for FY2012, where operational shortfall is not included but is likely to be at the same level as in FY2011 (PKR58 billion), which would reduce the FY2012 PSDP to PKR119 billion.

Sources: Finance Division's Federal budget: Budget in brief, 2008-09 for FY2009. Finance Division's Federal budget: Annual budget statement for 2009/10, 2010/11, and 2011/12 for FY2010, FY2011, and FY2012, respectively.

The policy measures recommended for Pakistan with regard to the availability of federal public financial resources are, therefore, to: (i) reduce the SBP's policy rate by at least 300 basis points to 10.5 percent in FY2012 to free up an additional estimated PKR225 billion for the federal PSDP. This will also restore growth to the economy. High interest rates are the IMF's prime instruments aimed at stabilizing the economy in developing countries by reducing inflation and growth. However, the fiscal deficit will have to be contained and the present policy of federal borrowing only from the banking system (and not from the SBP) continued. The SBP will have to fight inflation using the still high interest rates as well as other monetary instruments, and/or to mobilize additional resources through taxation (discussed further below). 
A review of Pakistan's tax revenues (Table 5) indicates the overwhelming role of income taxes (on individuals and corporations) in direct taxes, and the dominant position of sales tax and reduced role of customs duties and federal excise in indirect taxes. This reflects the effects of the IMF's free-market ideology, which was both imposed on and willingly adopted by Pakistan during the IMF program period (FY2009FY2011) and which continues to date.

Table 5: Pakistan's Federal Tax Revenues

(In PKR billion, current prices)

\begin{tabular}{lrrrr}
\hline & FY2009 & FY2010 & $\begin{array}{c}\text { FY2011 } \\
\text { (Revised Est.) }\end{array}$ & $\begin{array}{c}\text { FY2012 } \\
\text { (Budget) }\end{array}$ \\
\hline Total tax revenues (1+2) & 1,180 & 1,483 & 1,679 & 2,074 \\
Direct taxes & 461 & 540 & 627 & 744 \\
Income taxes & 443 & 520 & 603 & 719 \\
Workers Welfare Fund & 12 & 16 & 20 & 25 \\
Capital value tax & 6 & 4 & 4 & - \\
Indirect taxes & 719 & 943 & 1,052 & 1,330 \\
Custom duties & 145 & 165 & 173 & 206 \\
Sales tax & 457 & 540 & 655 & 837 \\
Federal excise & 116 & 134 & 133 & 157 \\
Petroleum levy* & 112 & 102 & 90 & 112 \\
Islamabad Capital & 1 & 1 & 1 & 2 \\
Territory taxes & & & & neg. \\
Airport tax* & neg. & neg. & neg. & . \\
\hline
\end{tabular}

$\mathrm{FY}=$ fiscal year.

* These taxes are not FBR taxes; all other taxes are FBR taxes.

Sources: Finance Division's Federal budget: Budget in brief, 2008-09 for FY2009. Finance Division's Federal budget: Annual budget statement for 2009/10, 2010/11, and 2011/12 for FY2010, FY2011, and FY2012, respectively.

Tax policy economists have focused primarily on the possibility of reviewing and strengthening the capital value tax on property transactions in order to increase direct tax revenues (Beaconhouse National University, 2011, pp. 103-106). Unfortunately, this proposal falls foul of the $18^{\text {th }}$ Amendment to the Constitution, which removed taxes on capital gains on immovable property from the Federal Legislative List. There is very little appetite in the system to increase income taxes on individuals or corporations, or to increase workers' welfare taxes on the profits of corporations. In fact, the special revenue measures imposed by the federal government in March 2011-including a 15 percent surcharge 
on income tax-were largely abolished in the FY2011-12 budget, and the income tax regime prevalent earlier restored.

Similarly and rather strangely, given the resources-constrained situation, many of the other special revenue measures of March 2011 relating to indirect taxes-particularly the increase in the rate of the sales tax from 16 to 17 percent-and the additional special excise taxes were also reversed. The special measures were expected to add PKR40 billion in additional revenues in the last quarter of FY2011. The reduction in the sales tax rate was particularly pointless since manufacturers had already adjusted their prices upward earlier and did not reduce prices as a result of the reduction. However, some of the special economic measures, including the removal of zero ratings for a few exempted sectors (particularly agricultural tractors), have been retained.

On the whole, the focus of the current FY2012 budget is to reduce federal excises (15 out of 46 were removed from the Excise Law) and almost eliminate regulatory duties (392 out of 397 were abolished, and only regulatory duties on luxury vehicles, cigarettes, arms and ammunition, betel nuts, and sanitary tiles have been retained). Similarly, the FY2012 budget approved that federal excise duty on cement be phased out in three years with a reduction of PKR200/MT in FY2012 and equal reductions of PKR500/metric ton in the next two years, giving a windfall profit gain to cement manufacturers. It was also announced that the federal excise duty on beverages was being phased out by reducing it to 6 percent in FY2012 and abolished the following year. These revenue losses were to be compensated for by (i) the removal of selected exemptions and zero ratings on sales taxes (in part continuation of the special economic measures mentioned above), (ii) an upward revision of the federal excise duty on cigarettes, (iii) revision of the rate of tax in lieu of VAT on commercial importers from 2 to 3 percent, and (iv) improving tax compliance (Government of Pakistan, 2011c).

The policy measures recommended for Pakistan with regard to additional taxation measures are, therefore, to: (i) increase the sales tax rate from its present level of 16 percent to 18 percent; (ii) increase the customs duty on all imports (excluding petroleum products, raw materials, and security-related imports) by 10-20 percent as recommended earlier, which will also benefit the balance of payments by restricting imports and helping avert a sharp depreciation of the exchange rate; and (iii) increase federal excise duties and the petroleum levy by extending it to domestically produced raw and compressed natural gas. This is particularly important given the windfall gains that will further accrue to domestic natural gas 
field operators as the Iranian natural gas (to be priced at approximately twice the present domestic gas prices) is brought on stream into Pakistan by the Iran-Pakistan gas pipeline by 2014 .

\section{Conclusion}

The analysis presented in this paper indicates that Pakistan faces interesting challenges on both the balance of payments account and the public finance account. The emerging balance of payments problems resulting from the suspension of the IMF program and the cessation of US cash logistics support can be dealt with by: (i) allowing the interbank foreign exchange market to work and accepting an orderly depreciation of the exchange rate in this market by about 5-15 percent or to PKR90100/dollar; (ii) imposing import surcharges of 10-20 percent on nonessential imports; and (iii) reinstating the additional requirements (including cash) on import letters of credit, which have recently been withdrawn by the SBP.

The public finance issues on the expenditures side can be resolved primarily by: (i) reducing the SBP policy rate by at least 300 points, which would reduce debt amortization payment; and (ii) using these savings on amortization payment to restore the federal PSDP for completing suspended ongoing important infrastructure projects (particularly roads, dams, power, and education and social sector projects). Public finance tax-related issues can be resolved by: (i) increasing the sales tax rate from 16 to 18 percent; (ii) increasing customs duties by 10-20 percent on nonessential imports, which is also required to manage the balance of payments; and (iii) increasing regulatory and excise duties and restoring their original coverage. By adopting these measures, Pakistan will be able to do without a follow-up IMF program, restore multilateral institution project lending, substitute its own resources for US cash logistics support, and restore much needed growth to the economy. 


\section{References}

Beaconhouse National University. (2011). Fourth annual report: State of economy: Devolution in Pakistan. Lahore: Institute of Public Policy.

Government of Pakistan. (2008). Federal budget: Budget in brief, 2008-09. Islamabad: Finance Division.

Government of Pakistan. (2009). Federal budget: Annual budget statement, 2009-10. Islamabad: Finance Division.

Government of Pakistan. (2010). Federal budget: Annual budget statement, 2010-11. Islamabad: Finance Division.

Government of Pakistan. (2011a). Annual plan, 2011-12. Islamabad: Planning Commission.

Government of Pakistan. (2011b). Federal budget: Annual budget statement, 2011-12. Islamabad: Finance Division.

Government of Pakistan. (2011c). Federal budget: Budget speech, 2011-2012. Islamabad: Finance Division.

Government of Pakistan. (2011d). Pakistan Economic Survey 2010-11. Islamabad: Finance Division, Economic Adviser's Wing.

State Bank of Pakistan. (2006). Annual report 2005-2006: Review of the economy. Karachi: Author.

State Bank of Pakistan. (2007). Annual report 2006-2007: Review of the economy. Karachi: Author.

State Bank of Pakistan. (2008). Annual report 2007-2008: Review of the economy. Karachi: Author.

State Bank of Pakistan. (2009). Annual report 2008-2009: Review of the economy. Karachi: Author.

State Bank of Pakistan. (2010a). Annual performance review, 2009-10. Karachi: Author.

State Bank of Pakistan. (2010b). Annual report 2009-2010: Review of the economy. Karachi: Author.

State Bank of Pakistan. (2011). Monetary policy statement, July 2011. Karachi: Author. 